\title{
The potential impact of entrepreneurship education on doctoral students within the non-commercial research environment in Chile
}

\author{
Chilean doctoral programs in science and technology generally do not consider \\ entrepreneurial training within their curricula. Taking an entrepreneurial competency \\ approach, we explore the potential impact of introducing an entrepreneurship education \\ course to doctoral students based within a non-commercial research environment. We \\ identified two main areas of possible impact: the potential effects upon doctoral research \\ projects and the potential effects upon the doctoral students themselves. We followed the \\ learning experiences of science and technology $\mathrm{PhD}$ students before, during, and a year \\ after an entrepreneurial course through a multiple case study research design. Our results \\ suggest that entrepreneurship education has a positive impact upon the development of \\ student's creative problem solving and communication skills. This was reported to have a \\ generally positive effect upon the students' doctoral projects and on the student's self- \\ efficacy and entrepreneurial intentions. We conclude that entrepreneurship education \\ complements traditional doctoral training for students within a non commercial academic \\ setting.
}

Keywords: doctoral education; doctoral student; entrepreneurship education; entrepreneurial skills; entrepreneurial intention

This work was supported by CONICYT-CHILE under Grant Fondecyt de Iniciación No 11121617.

\section{Introduction}

Entrepreneurship is considered a key economic activity as it fosters innovation and economic growth (Acs 2006; Acs and Szerb 2007). Similarity, entrepreneurs are understood as economic agents that "develop a special competence in interpreting information that signals the existence of opportunities to create new wealth" (Fiet 2002: 3). Consequently, entrepreneurial skills are 
increasingly being considered fundamental to promote more entrepreneurial economies (Binks, Starkey and Mahon 2006; Galloway et al. 2005). As a result, entrepreneurship courses are becoming more prevalent in higher education programs, even in those not directly related to business. They are argued to have a positive impact on students' capabilities and career paths (Arranz et al. 2016; Greene and Saridakis 2008). Some authors even argue that the entire modern university should take an entrepreneurial approach (Abreu et al. 2016; Etzkowitz 1983; Gibb 2007) where entrepreneurship education should play a central role (Gibb 2005).

Entrepreneurship education research has argued for the predominantly positive impact of entrepreneurial training in different educational contexts (Nabi et al. 2017). Studies have been shown impact at the undergraduate (e.g.: Mathisen and Arnulf 2013; von Graevenitz, Harhoff, and Weber 2010) and Master's level (e.g.: Rauch and Hulsink 2015). Studies have shown efficacy across different parts of the world (Mustar 2009; García-Rodriguez et al. 2016; Harker, Caemmerer, and Hynes 2015; Francoise, Janviere, and Ding 2016) and in different academic disciplines (Lüthje and Franke 2003; Mustar 2009; Täks, Tynjälä, and Kukemelk 2015; Maresch et al. 2015; Ortiz-Medina et al. 2015). It is clear that entrepreneurship education research in higher education has grown considerably in the last decades (Béchard and Grégoire 2005b; Kuratko 2005; Loi, Castriotta, and Di Guardo 2016).

However, studies analysing the impact of entrepreneurship education at the doctoral level are still scarce, and the specific impact of different pedagogical methods within different contexts remains an area of considerable debate (Lean 2012; Bienkowska, Klofsten, and Rasmussen 2016). We propose that entrepreneurship education can make a relevant contribution to enhance doctoral training and that therefore more research is needed to explore the impact of entrepreneurship education within this unique and specific context. Doctoral students are a 
fundamental part of the academic research environment (Enders 2002). Doctoral students are trained to create new knowledge as well as to provide empirical and intellectual contributions to the research of senior scholars (Bansel 2011). Salter and Martin (2001) showed that these students make a significant contribution to economic impact as they deploy this knowledge in society. Yet, their training generally does not consider the development of an entrepreneurial mind-set and concomitant skills (Roberts 2002; Warry 2006). This situation is most keenly felt within a context such as Chile where the commercialisation of research is a relatively new activity (Gobierno de Chile 2013; Instituto Nacional de Propiedad Industrial 2016).

This research represents an effort to explore whether entrepreneurship education could enrich doctoral training in science and technology in terms of enhancing innovation within a non-commercial research environment. To do so, we adopt an entrepreneurial competence approach, observing learning outcomes such as changes in creative problem solving and opportunity identification at the individual level (Nabi et al. 2017). We investigate two main areas of potential impact: First, potential impact related to doctoral research projects. Second, potential impact related to the doctoral students themselves.

Adopting a qualitative research approach, the study considered two entrepreneurship courses of one semester of duration each offered as elective courses across the different doctoral programs of science and technology at the University of Santiago, Chile. In order to capture the experience of the participating students, in-depth interviews were conducted at the beginning, at the end and one year after the course completion. Various data collection instruments were used in each interview such as in-depth interviews and opportunity identification assessments.

The paper proceeds by reviewing literature that explores the relationship between doctoral training and entrepreneurship education. We then review empirical work considering 
the potential impact of entrepreneurship education upon doctoral students competencies and aspirations. Then, we explain our research approach. We continue by presenting our results. Finally, we discuss the implications of our results for education theory and practice and present our main conclusions.

\section{Doctoral Training and Entrepreneurship Education}

Studies examining doctoral education in general are gaining increased attention by researchers and policy makers (Gardner 2009; Lahenius 2012). Scholars argue that this kind of education is facing important changes in purpose, content and outcomes (Bao, Kehm, and Ma 2016; Kot and Hendel 2012; Hancock, Hughes, and Walsh 2015). Indeed, scholars are observing that both doctoral programs and students are placing greater attention to research projects and future career paths that provide a stronger and more explicit link to the needs of industry (Malfroy 2011; Strengers 2014; Servage 2009).

Etzkowitz (1983) observed a shift in the traditional role of scientists towards individuals able to collaborate with the industry and to commercially exploit their research, which he argued was symptomatic of a new paradigm for universities. Subsequently, scholars introduced the concept of Academic Capitalism to describe the marketlike behaviours of certain faculty and academic institutions towards seeking alternative sources of funding (Slaughter and Leslie, 1997; Slaughter and Rhoades., 2004). Some scholars have argued that this phenomenon is undermining traditional university values and jeopardizing the academic mission (Bok, 2003; Jaeger and Thornton, 2005; Kezar, 2004). Other scholars have a more positive view arguing that it can enhance the scholarly mission of the University, if effectively moderated (Etzkowitz, 2003; McMillan et al., 2000; Shane, 2004). 
Over the last two decades, scholars have observed that the proportion of PhDs moving from academe to industry after graduation was increasing and was thereby fostering technology transfer in new ways (Enders 2002; Lester 2004; Stephan et al. 2005; Bentley and Hooley 2010). In recent years, scholars have reported how doctoral students act as an effective interface for collaboration between universities and industry agents (Bienkowska and Klofsten 2012; Thune 2009). Some studies have also focused on doctoral students' perceptions and views about entrepreneurial issues, which appear to be significantly influenced by their local context (Loxley and Seery 2012). For instance, studies have focused on student socialization in the context of STEM doctoral education (Mars et al., 2014; Mendoza, 2007; Szelényi, 2013) and have shown that faculty mentorship can have a profoundly positive or negative influence upon student's perceptions of industrial research (Mars et al., 2008).”

Within this debate, studies analysing the particular impact of entrepreneurship education on doctoral training are still scarce (Lean 2012; Bienkowska, Klofsten, and Rasmussen 2016). In institutions with a long tradition of the commercialisation of research, $\mathrm{PhD}$ students have been reported to be generally positive in their views regarding the development of entrepreneurial skills during their training (Lean 2012) and also to be more receptive to university information and support towards academic entrepreneurship than more senior academics (Bienkowska, Klofsten, and Rasmussen 2016). Other studies have reported variance in students' attitudes towards entrepreneurship across different national contexts. For example, Walsh, Hargreaves, and Hillemann-Delaney (2014) conducted a study in which Chinese PhD students appeared to have a positive view about entrepreneurship, at the same time that British $\mathrm{PhD}$ students tended to have a more negative view about relating entrepreneurship to research. Moreover, within the UK 
context, doctoral students in the science and technology areas appear particular reluctant to engage with entrepreneurial training (Department of Business, Innovation and Skills 2015).

On the other hand, scholars and policy makers are starting to consider entrepreneurship education as a promising way to foster technology transfer via spin out company formation by making calls for a greater consideration of entrepreneurial training within the doctoral student agenda (Lean 2012; Mars, Bresonis, and Szelényi 2014; Warry 2006). Different calls have been made to highlight how enterprising skills can enhance the career development of doctoral researchers more generally (Disney et al. 2013; Viate 2012). For example, in the UK the Vitae initiative, through interviewing a series of researchers, identified a series of key competences developed by successful researchers who remained within academe, among which entrepreneurial competences such as creativity, problems solving, team working and communication skills were proposed to play an important role (Vitae 2011).

However, empirical evidence underpinning those calls is still scarce. In the same vein, Lean (2012) pointed out that questions remain as to whether entrepreneurial skills are best developed within the context of a formal doctoral training or through other employer training and development inputs.

\section{The case for doctoral entrepreneurship education}

The research that we report in this paper represents an effort to explore empirically the potential impacts of entrepreneurship education upon doctoral training. We argue that exploring this issue is relevant as contemporary empirical work suggests at least five different aspects of impact that entrepreneurship training could provide. First, doctoral programs are not always required to produce innovation (Roberts 2002; Warry 2006). Consequently, some scientific discoveries 
remain only as academic outputs and never turn into new solutions that could improve wellbeing. Entrepreneurship education could foster innovation from doctoral projects, since it can provide a space to envision and explore potential applications of scientific and technological research.

Second, doctoral entrepreneurship education could enhance technology transfer since doctoral students can act as an effective interface between university and industry (Thune 2009; Bienkowska, and Klofsten 2012; Stephan et al. 2005). If future scientists are trained in entrepreneurship, they will arguably be more able to understand the commercial aspects of academic research and more able to transfer the appropriate knowledge to industry by solving industrial problems or creating new ventures.

Third, entrepreneurship education could complement doctoral training by encouraging the development of entrepreneurial skills that could be useful for entrepreneurial activities as well as other doctoral activities such as presenting results or solving research problems (Warry 2006). Thus, the inclusion of entrepreneurial training could help to overcome weaknesses identified in traditional doctoral education related to entrepreneurial knowledge as well as interpersonal and communication skills (Roberts 2002).

Fourth, as several scholars and public initiatives have recognised (e.g.: Disney et al. 2013; Vitae 2012), entrepreneurial competences are argued to be an important part of the set of attributes that contribute to enhance "the personal, professional and career development of researchers in higher education" (Vitae 2011, 1). Therefore, entrepreneurship education can contribute to the future career path of doctoral students even if they remain in academe.

Fifth, since an important part of university research is performed by doctoral students (Enders 2002), to include entrepreneurship education as a part of the PhD training is to influence 
an important share of the university research with an entrepreneurial perspective, promoting more entrepreneurial universities (Bienkowska, Klofsten, and Rasmussen 2016). Furthermore, given that doctoral students tend to move to a different region after graduation (Stephan et al. 2005), they can take with them not only new knowledge, but also an entrepreneurial mind-set and a more entrepreneurial approach to academic research. This is a general challenge within the academic disciplines of science and technology where the institutional culture is predominantly non-commercial (Becher and Trowler 2001).

Finally, we acknowledge that integrating entrepreneurship education within STEM doctoral education could also have potential downsides such as making students more concerned with commercial concerns than research and giving them a partial view of the academic vision. This provides additional support to study this issue empirically.

To explore the potential impacts of entrepreneurial education upon a non-commercial doctoral education environment we have adopted a competence approach. This assumes that students are active participants in the co-construction of their knowledge and that "individual learning results from the interactions between external and internal factors" (Béchard and Grégoire 2005a: 115). In this approach, learning is associated with knowing how to solve complex problems in particular contexts (Béchard and Grégoire 2005a).

We argue that it is important to explore to what extent a doctoral project could be affected as a result of the students' participation in an entrepreneurship course, especially in a context such as Chile, where the commercialization of research is still in an early stage (Gobierno de Chile 2013; Instituto Nacional de Propiedad Industrial 2016). In Chile, producing peer reviewed journal publications is the main aim of the doctoral process even in programs where students do not have to write a thesis. Here it is atypical for $\mathrm{PhD}$ students to report their 
work to industrialists or policy makers and doctoral projects focus predominantly on producing publications for the academic world. We contend instead that entrepreneurship training with an important experiential component could foster the generation of innovations in projects that otherwise would not necessarily consider the productions of applied solutions. In this context, we present our first research question to explore:

Could entrepreneurship education enhance the research projects of doctoral students of science and technology in Chile?

We also sought to explore potential impacts of entrepreneurship training on doctoral students themselves. There is abundant literature reporting the positive impacts of entrepreneurship education on different types of students. We followed the findings of Martin, McNally, and Kay (2013) as a framework to explore this issue. In a meta-analysis examining the formation of entrepreneurial human capital considering 42 studies, they identified main individual assets positively linked to entrepreneurship education namely: entrepreneurial knowledge \& skills, entrepreneurial intention and perceptions on entrepreneurship. While these results show that entrepreneurial education produce positive effects in terms of skills, intentions and perceptions, more research is needed to explore further the potential impact of entrepreneurial education in terms of, for instance, patenting and new venture creation (Nabi et al. 2017).

Regarding entrepreneurial knowledge \& skills, many studies have showed that entrepreneurship education contributes to the development of different entrepreneurial skills, particularly creative problem solving and opportunity identification (e.g.: Karlsson and Moberg 2013; Lackéus 2014; DeTienne and Chandler 2004; Fiet 2002; Muñoz, Mosey, and Binks 2011). Therefore, our attention will first focus on observing possible changes in these areas. 
Regarding entrepreneurial intention and perceptions, several studies have showed that entrepreneurship education can contribute to enhance entrepreneurial intentions (e.g.: Roman and Maxim 2015; Rauch and Hulsink 2015; Souitaris, Zerbinati, and Al-Laham 2007). Although other studies have raised concerns (e.g.: Fayolle and Gailly 2009; von Graevenitz, Harhoff, and Weber 2010; Oosterbeek, Praag, and Ijsselstein 2010). It seems that variables such gender, type of student among others may be moderating the relationship (e.g.: Karimi et al. 2016; Shinnar, Hsu, and Powel 2014; Wang et al. 2016).

Despite certain contradictory evidence in the literature, it is clear that there is abundant evidence that entrepreneurship education has an impact on students. Consequently, we contend that it is important to explore the particular impacts of entrepreneurship education on the training of doctoral students. In this context, we present our second research question to explore:

Could entrepreneurship education enhance the development of entrepreneurial skills and intentions of doctoral students of science and technology in Chile?

\section{Methodology}

\section{Research Context}

We examined our research questions in Chile. We argue that this country is revealing to observe because this country is one of the most productive in Latin America in terms of research (Gobierno de Chile 2013). Although, a few years ago the support to innovate from academic research was quite scarce (Benavente 2005), it has been growing over the last decade (Gobierno de Chile 2013; OECD 2008). However, most of the investment comes from the state at the same time that the great majority of companies are still reluctant to engage with universities in innovation projects (Ministerio de Economía, Fomento y Turismo 2014). Furthermore, most 
Chilean doctoral programs do not consider entrepreneurship education as a part of their curricula. We argue that this specific context is relevant to conduct our research given that particularly little attention has been paid to empirically explore the potential impacts of entrepreneurship education on doctoral training within a non-commercial research environment.

\section{Research Design}

We examined our research questions using a multiple case study research design, an approach argued to help with "understanding the dynamics present within single settings" (Eisenhardt $1989,534)$ and allowing researchers "to retain the holistic and meaningful characteristic of reallife events" (Yin 2003, 2). In our research we focused on doctoral students as cases with the purpose of examining their learning experiences from a longitudinal perspective and across a wide range of potentially influential factors. We took this perspective to better understand the impact of entrepreneurship education on individuals, which is in line with the entrepreneurial competence approach (Nabi et al, 2017).

In order to carry out the research there were two entrepreneurship courses of one semester each, offered as elective courses to a variety of $\mathrm{PhD}$ programs in science and technology at the University of Santiago, Chile, the Chilean public university with the highest number of patents issued each year (Inapi 2016; Inapi 2011). Chilean universities, including the University of Santiago, conduct predominantly basic research (Balbontín, Roeschmann, and Zahler 2018). At the same time, Chilean universities have weak collaboration links with Industry (Ministerio de Economía, Fomento y Turismo 2014). As a result, most doctoral applicants tend to have a traditional academic approach to research rather than a more commercial mindset. 
We followed the learning experiences of each student from the beginning of an entrepreneurship course until more than a year after the end. We observed any changes in their research projects as well as changes in performances, self-perceptions, intentions and views related to entrepreneurship.

16 students in total enrolled in those two courses out of a total population of 183 science and technology PhD students. They came from doctoral programs in food processing, neuroscience, automation, computer science, process engineering, and materials. The total of students enrolled in those 6 programs was 68 in 2013. They were invited to participate at the beginning of each course; 13 students agreed to participate. The profiles of the students participating, which are shown below, were quite diverse. For example, they had different prior entrepreneurial exposures, gender and entrepreneurial intentions before the course. This student diversity contributed to maximize the external validity of the study (Yin 2003) as well as to minimize self-selection bias.

Insert Table 1 about here

The courses consisted of two main parts. The first part focused on theoretical issues related to creativity, innovation and entrepreneurship. This part was complemented with activities and exercises oriented to stimulate students' creativity and opportunity identification. At this stage, students were organised into interdisciplinary groups to allow a diversity of perspectives when analysing problems. The second part of the course focused on developing a business project that should consider knowledge from the different disciplines represented in each group. First, students should identify a problem associated with an unmet need in any area 
they wanted to explore. Then students applied creative problem solving techniques (Lumsdaine and Binks 2005) to find solutions to the problem previously identified, which should involve scientific and technological knowledge. Finally, students had to present their projects to the University incubator to receive feedback about the commercial possibilities of their ideas. Students were also required to complete a learning report to help them to better assimilate their experiences during the course.

\section{Data Collection Procedures and Methods}

To capture the learning experiences of participants, several interviews were carried out at different moments in time between 2013 and 2015. The first round of interviews was carried out at the beginning of the course to capture prior entrepreneurial exposures, initial performances, initial self-perceptions, initial entrepreneurial intentions, and views on entrepreneurship among other issues which gave us an important insight of the students' backgrounds. The second round of interviews was conducted at the end of the course to capture changes on performances, selfperceptions, entrepreneurial intentions, views on entrepreneurship and any other important variations that researchers were able to observe. The third round of interviews was carried out after a year of the end of the course to capture similar changes as those observed at the end of the course.

In each interview, different methods were used. The main data collection techniques were questionnaires of open-ended questions based on previous studies which allowed students to explain in more detail their experiences.

Changes in opportunity identification performance were assessed through a procedures used in previous studies (DeTienne and Chandler 2004; Muñoz, Mosey and Binks 2011). This 
consisted of assessing the quality and quantity of the opportunities identified by the students (Gaglio, 2004; Hills et al., 1997; Hills \& Shrader, 1998; Shane, 2000; Shepherd \& DeTienne, 2005; Singh et al., 1999). This approach was applied to the students at the beginning and after the end of the module where students were asked to list any business opportunities that they could think of. The quality of the opportunities identified was then assessed by several habitual entrepreneurs (i.e. entrepreneurs who have started more than one business) who used a scale previously applied in other studies (DeTienne \& Chandler, 2004; Fiet, 2002; Muñoz et al., 2011) to help their evaluation. According to previous studies habitual entrepreneurs has been reported as having a well-developed capability to identify opportunities (Chandler \& Jansen, 1992; Fiet et al., 2004; McGrath \& MacMillan, 2000) and able to identify more opportunities than novice entrepreneurs (Ucbasaran et al., 2003; Ucbasaran et al., 2006) and consequently able to evaluate better opportunity quality rather than other possible evaluators.

Finally, researchers benefited from participative observation because they were also involved in the delivery of the course. This allowed researchers to have a great immersion during the research process, an excellent understanding of each student's learning process and therefore a profound comprehension of the data collected. One researcher was not involved in the delivery of the courses to minimise potential bias.

\section{Data Analysis}

To analyse the data in relation to our research questions we followed an iterative approach. We began by considering the students' testimony regarding to their learning experiences. Each interview was transcribed after being conducted. The interview transcripts were read and re-read 
as data were collected. Emerging themes were refined through pattern matching (Yin 2003) as this process progressed and was checked through the repeated interviews with students. Here as the analysis proceeded, the focus moved from exploring data to empirical scrutiny of our research questions (Van de Ven and Poole 2002; Yin 2003). Then we identified categories within each question by triangulating data emerging from transcriptions with the data emerging from the other techniques used. This was followed by a second-order analysis to develop explanations within each question through explanation building (Yin 2003).

\section{Results}

\section{Impacts on doctoral projects}

As reported by the students, the course had direct and indirect impacts on their doctoral research which were categorized as more applied projects and more solutions to research problems (See table 2). These impacts were perceived by 9 out of the 13 students participating in the research, which is of particular interest because some of these 9 students could not modify their doctoral projects because they were part of major investigations associated with their supervisors.

Insert Table 2 about here

First, 8 students recognized that the course had helped them incorporate a more applied vision to their projects, since after the course it was much easier to see potential applications from their research than before. In fact, before the course some of them did not consider 
commercial applications for their projects as part of their research objectives. For example, Renato pointed out at the end of the course that:

"Now I see more applications to my doctoral project, I found that you can get much more out of it than I thought"

Second, 7 students reported that problem-solving and idea-generation techniques learned during the course had helped them to find solutions to various challenges that came up during their studies. Therefore, what was learned helped facilitate the doctoral process. For example, David pointed out at the end of the course that:

"The course was fundamental because it allowed me to look at the problems from other perspectives and other prisms, it helped me to look for more creative solutions or (at least) different to the ones I was looking at, even looking outside the scientific context to be able to explain the phenomena that I am seeing and to be able to answering the question that I had not been able to answer until now, it helped me a lot"

\section{Impacts on Entrepreneurial Skills}

We found important evidence that the course contributed to enhance both, the development of students' entrepreneurial skills and their self-perceptions of their capabilities. We observed that the course helped students to develop the capacity to identify opportunities, the ability to communicate their ideas clearer and more persuasively, and at the same a better understanding of how to carry out an entrepreneurship project.

First, we observed that the great majority of participants developed their capacity to identify opportunities during the course, despite important differences they exhibited in terms of disciplines, prior entrepreneurial exposure and entrepreneurial intentions at the beginning of the 
course. Through the opportunity assessment we presented in the methodology section, we observe that 10 out of 13 students were able to identify more and better opportunities once the course finished or even a year after. Even more students reported a self-perceived increase in their opportunity identification capabilities after the course. The positive impact of entrepreneurship education on the enhancement of opportunity identification capabilities had been observed in previous studies (e.g.: DeTienne and Chandler 2004; Muñoz, Mosey, and Binks 2011). However, this is the first study, to our knowledge, to observe the same tendency at the scientific doctoral level where they had experienced little exposure to entrepreneurial or managerial issues in their academic settings.

Second, 9 students reported that the course also helped them to improve their communication and "sale of ideas" skills which they also considered to be relevant for their doctoral training, noting that those kind of abilities were missing in their programs (See table 3). For example, Gloria pointed out at the end of the course that:

"Now it has been easier for me to lookfor funding sources because now I know what to do, what to say, how to deal with it, what to write, what to think about the client"

Insert Table 3 about here

Finally, 4 students reported that after the course they had a better understanding of how to approach an entrepreneurship project (See table 3). For example, Roberto pointed out at the end of the course that: 
"Really good (the course) because it gave me fundamentals, I had like the restlessness and had made a couple of undertakings, and here I had theoretical and practical foundations of what to do, how to do, why to do it and what alternatives I have"

In conclusion, we observed that the course did enhance the development of students' entrepreneurial skills and self-perceptions of it, the communication skills useful for "selling" such opportunities and also the understanding of how to undertake them. This provides evidence to support the idea that entrepreneurship education could enhance the development of entrepreneurial skills at the doctoral level within a non commercial context.

\section{Impacts on Entrepreneurial Intentions}

In terms of entrepreneurial intention, 10 students stated at the beginning of the course that they had some degree of intention to launch their own business in the future. After the course, those students who had already expressed a positive entrepreneurial intention reported an increase of it (See table 4).

Insert Table 4 about here

First, 6 students indicated after the course that they intended to commercially exploit the results of their doctoral research and / or develop a company, compared to the beginning of the course. For example, Dubraska noted at the beginning of the course a low degree of entrepreneurial intention:

"Well, it would be ideal, but so far I have not consider it (commercially exploiting research results)” 
However, at the end of the course, her intention increased significantly:

"Developing a company from my research is my next project, because it is something I want to do now"

Second, 5 students responded that they had a greater entrepreneurial intention after finishing the course, but not restricting their options solely to their research. For example, Wladimir pointed out at the end of the course that:

"Not from my particular research, but I have other ideas. I have ideas that I would like to be able to exploit to the fullest and I know now that they could have some potential"

Third, 5 students reported that the course allowed them to remove mental barriers that hindered their entrepreneurial intention. For example, Mauricio said:

"It served me mainly to break the paradigm I had of entrepreneurs. I conceived them as enlightened people ... I realized that it is more about the desire of doing something and want to develop it, than being a brilliant person"

In the case of the students that reported no interest in starting a business in the future at the beginning of the course, their entrepreneurial intentions did not undergo major changes. However, the three of them manifested a higher interest in exploring this possibility in the future. In other words, although they were not convinced to start a business in the future, they were at least more open to the possibility. For example, Jose pointed out "I'm not very sure, but I think so, more than before." "Before, maybe it was zero, now I'm like maybe, but I'm not 100\% sure" ( $2^{\text {nd }}$ Interview). "I think so ... I think it is more feasible" ( $3^{\text {rd }}$ interview) and Roberto said "Now I know what to do if a want to transform my project in a kind of business idea" ( $2^{\text {nd }}$ Interview).

In conclusion, most students increased their intentions to start a business after the course, including ideas that were not necessarily related to their doctoral research, which support the 
idea that entrepreneurship education can help to enhance entrepreneurial intentions of science and technology doctoral students.

\section{Discussion}

\section{Theoretical Entrepreneurship Education Implications}

Our research provides evidence that supports and expands the idea, suggested in previous studies, that entrepreneurship education has several positive effects in terms of competences (Béchard and Grégoire, 2005; Nabi et al., 2017), adding that similar results were observed in the neglected research context of doctoral education in a non commercial setting. First, previous research has showed that the entrepreneurial classroom is a venue where different entrepreneurial competences can be developed (e.g.: Galloway et al. 2005; Karlsson and Moberg 2013; Lackéus 2014). Our research reports evidence showing that doctoral students in science and technology indeed developed their opportunity-identification capabilities and other entrepreneurial skills. This is notable because it shows that entrepreneurial skills can be developed even in people whose backgrounds and career paths are not directly related to business contexts.

Second, our research also confirmed the idea that entrepreneurship education has a positive impact on the students' entrepreneurial intentions (e.g.: Rauch and Hulsink 2015; Souitaris, Zerbinati and Al-Laham 2007; Pruett et al. 2009). However, our results add a nuance to the prior art. The entrepreneurial course had a more significant impact on those students whose prior entrepreneurial intention was high. It seems that students with a high prior entrepreneurial intention tend to reassure their disposition as one of the results of their learning. In contrast, doctoral students whose prior entrepreneurial intention was low also tended to 
maintain their low disposition to start a business in the future. Thus, our results suggest that students, whose backgrounds and career paths are not directly related to business contexts, do not necessarily increase their entrepreneurial intention after receiving entrepreneurial training. This might be reconciled with previous studies showing that entrepreneurship education does not always increase entrepreneurial intentions (e.g.: Fayolle and Gailly 2009; von Graevenitz, Harhoff, and Weber 2010; Oosterbeek, Praag, and Ijsselstein 2010). It should be highlighted nonetheless that even though those students reported that they did not want to start a business in the future, they still considered entrepreneurial skills as useful for their doctoral training.

\section{Education Practice Implications}

Our results also have important implications for education practice. First, our results suggest that entrepreneurship education could be an important complement to traditional doctoral training. Our results show that entrepreneurship training can enhance the identification of practical applications of scientific and technological research. In this way, we contend that entrepreneurship education can help doctoral programs on science and technology to promote technology transfer and innovation among their students and also to provide a fruitful space to explore academic entrepreneurship.

Second, students participating in our research reported that they were able to develop better communication, problem-solving and opportunity identification skills after receiving entrepreneurial training. Thus, our results suggest that entrepreneurship education can also be effective in the development of such competences both at the doctoral level and in a context such as Chile, where the support for a more enterprising dimension of the research is still at an early stage. 
Third, scholars and public initiatives have highlighted the importance of developing certain competences that could enhance the personal and professional development of doctoral researchers (e.g.: Disney et al. 2013; Vitae 2012). Our results provide evidence not only that entrepreneurial training can enhance the development of such competences, but also that those competences are relevant for their research training. Indeed, the students participating place a particular emphasis for these kinds of skills, highlighting their relevance during the doctoral process and the marginal emphasis that their programs gave to their development.

\section{Limitations and Future Research}

Since our research was exploratory and conducted with a qualitative methodological approach, our results are not generalizable. Our main goal was to explore the potential impact of entrepreneurship education in a rather neglected context to observe any benefits and identify areas for further research.

We propose that more research is needed in non commercial settings to better understand how entrepreneurship education could help doctoral students to be more capable to identify commercial possibilities for their own research and how entrepreneurship education could promote patenting and new venture creation among doctoral students. On the other hand, more research is needed to continue exploring how entrepreneurship education could enhance interdisciplinary collaboration in non commercial settings. For example, entrepreneurship education could serve as a space where science and technology doctoral students could interact, for example, with MBA students or even with practitioners to begin to explore commercial applications of their own research projects. 


\section{Conclusions}

This paper explores the potential benefits of including entrepreneurship education in the training of doctoral students in a non commercial setting. First, our results provide evidence that entrepreneurship education at the doctoral level has a positive effect on students ${ }^{\prime}$ doctoral projects. Second, our results also suggest that entrepreneurship education can contribute in the development of entrepreneurial competences and intentions. This extends the findings of previous research into the under explored non-commercial research environment found in Chile. Our results suggest that entrepreneurial competences are useful for such doctoral students, because they equip them with competencies to better present and defend their ideas, to find solutions to problems more easily, to foresee potential research applications and to help them to generate connections for future collaboration. This contributes to the thesis that entrepreneurial competences contribute to the personal, professional and career development of doctoral students more generally.

\section{References}

Abreu, M., Demirel, P., Grinevich, V., and Karataş-Özkan, M. 2016. Entrepreneurial practices in research-intensive and teaching-led universities. Small Business Economics, 47(3), 695-717.

Acs, Z.J. 2006. How is entrepreneurship good for economic growth? Innovations, 1(1), 97-107.

Acs, Z.J., Szerb, L. 2007. Entrepreneurship, economic growth and public policy. Small Business Economics, 28, 109-122.

Arranz, N., Ubierna, F., Arroyabe, M.., Perez, C., and Fdez. de Arroyabe, J. 2016. The effect of curricular and extracurricular activities on university students' entrepreneurial intention and competences, Studies in Higher Education. 
Bansel, B. 2011. Becoming academic: a reflection on doctoral candidacy, Studies in Higher Education, 36(5), 543-556.

Bao, Y., Kehm,B., and Ma, Y. 2016. From product to process. The reform of doctoral education in Europe and China, Studies in Higher Education.

Balbontín, R., Roeschmann, J. A., and Zahler, A. 2018. Ciencia, Tecnología e Innovación en Chile: un análisis presupuestario.

Béchard, J. P., and Grégoire, D. 2005a. Understanding teaching models in entrepreneurship for higher education. In P. Kyro, and C. Carrier (Eds.), The dynamics of learning entrepreneurship in a cross-cultural university context: 104-134. Tampere, Finland: Faculty of Education, University of Tampere.

Béchard, J., and Grégoire, D. 2005b. Entrepreneurship education research revisited: The case of high education. Academy of Management Learning and Education, 4(1), 22-43.

Becher, T., and Trowler, P. 2001. Academic tribes and territories: intellectual enquiry and the culture of disciplines. Society for Research into Higher Education \& Open Univ. Press, Buckingham.

Benavente , J. 2005. Innovación tecnológica en Chile: Dónde estamos y qué se puede hacer. Journal Economía Chilena (The Chilean Economy), Central Bank of Chile, 8(1), 53-77.

Bentley, K., and Holley, T. 2010. What do researchers do? Career profiles of doctoral entrepreneurs. Vitae/Careers Research and Advisory Centre, Cambridge.

Bienkowska, D., and Klofsten, M. 2012. Creating entrepreneurial networks: academic entrepreneurship, mobility and collaboration during PhD education. Higher Education, 64, 207-222. 
Bienkowska, D., Klofsten, M., and Rasmussen, E. 2016. PhD students in the entrepreneurial university - perceived support for academic entrepreneurship. European Journal of Education, 51(1), 56-72.

Binks, M., Starkey, K., and Mahon, C. 2006. Entrepreneurship education and the business school. Technology Analysis \& Strategic Management, 18(1), 1-18.

Bok, D. 2003. Universities in the marketplace: The commercialization of higher education. Princeton, NJ: Princeton University Press.

Chandler, G.N. and Jansen, E. 1992. 'The founder's self-assessed competence and venture performance'. Journal of Business Venturing, 7(3), 223-236.

Department of Business, Innovation and Skills. 2015. Entrepreneurial Skills: literature and policy $\begin{array}{llllll}\text { review, } & \text { BIS, } & \text { UK. } & \text { Accessed }\end{array}$ https://assets.publishing.service.gov.uk/government/uploads/system/uploads/attachment_d ata/file/457533/BIS-15-456-entrepreneurship-skills-literature-and-policy-review.pdf

DeTienne, D., and Chandler, G. 2004. Opportunity identification and its role in the entrepreneurial classroom: A pedagogical approach and empirical test. Academy of Management Learning and Education, 3(3), 242-257.

Disney, T., Harrowell, E., Mulhall R., and Ronayne, M. 2013. Doctoral researcher skill development: learning through doing. Planet, 27(2), 14-20.

Einsenhardt, K. 1989. Building theories from case study research. Academy of Management Review, 14(4), 532-550.

Enders, J. 2002. Serving many masters: The PhD on the labour market, the everlasting need of inequality, and the premature death of Humboldt. Higher Education, 44(3), 493-517. 
Etzkowitz, H. 1983. Entrepreneurial scientists and entrepreneurial universities in American academic science. Minerva, 21(2), 198-233.

Etzkowitz, Henry. 2003. Research groups as “quasi-firms"': The invention of the entrepreneurial university. Research Policy, 32(1), 109-121.

Fayolle, A., and Gailly, B., 2009. Evaluation d'une formation en entrepreneuriat: prédispositions et impact sur l'intention d'entreprendre. Management, 12(3), 176-203.

Fiet, J. O. 2002. The Systematic Search for Entrepreneurial Discoveries. Quorums Books, Westport, CT.

Fiet, J.O., Clouse, V.G.H. and Norton Jr., W.I. 2004. 'Systematic search by repeat entrepreneurs', in Butler J.E. (Ed.), Opportunity Identification and Entrepreneurial Behavior. Greenwich, CT: Information Age Publishing.

Francoise, U., Janviere, N., and Ding, D. 2016. African S\&T Professionals Trained in Chinese Universities: Orientations towards Entrepreneurship. Science, Technology \& Society, 21(2), 296-314.

Gaglio, C.M. 2004. So what is an entrepreneurial opportunity? in Butler J.E. (Ed.), Opportunity Identification and Entrepreneurial Behavior. Greenwich, CT: Information Age Publishing.

Galloway, L., Anderson, M., Brown, W., and Wilson, L. 2005. Enterprise skills for the economy. Education + Training, 47(1), 7-17.

García-Rodríguez, F., Ruiz-Rosa, C., Gil-Soto, E., and Gutiérrez-Taño, D. 2016. Promoting entrepreneurship education among university students: design and evaluation of an intervention programme / Fomento de la educación emprendedora entre el alumnado universitario: diseño y evaluación de un programa de intervención. Cultura y Educación/Culture and Education, 28(3), 565-600. 
Gardner, S. K. 2009. The development of doctoral students - phases of challenge and support. ASHE Higher Education Report, 34(6), 1-14.

Gibb, A.A. 2005. Towards the entrepreneurial university. Entrepreneurship education as a lever for change. Policy paper No. 3. National Council for Graduate Entrepreneurship, Birmingham.

Gibb, A. A. 2007. Creating the entrepreneurial university: do we need a wholly different model of entrepreneurship? in: Fayole, A. (Ed.), Handbook of Research in Entrepreneurship Education, Volume 1. Edward Elgar Publishing Limited, Cheltenham, UK, pp. 67-103.

Gobierno de Chile. 2013. 2013 Año de la innovación: Innovación en Chile y desafíos para ser una economía del conocimiento, Chile. Accessed January 16, 2019. http://docplayer.es/22736003-2013-ano-de-la-innovacion-innovacion-en-chile-y-desafiospara-ser-una-economia-del-conocimiento.html

Greene, F., and Saridakis, G. 2008. The role of higher education skills and support in graduate self - employment, Studies in Higher Education, 33(6), 653-672.

Hancock, S., Hughes, G., and Walsh, E. 2015. Purist or pragmatist? UK doctoral scientists' moral positions on the knowledge economy, Studies in Higher Education.

Harker, M., Caemmerer, B., and Hynes, N. 2015. Management Education by the French Grandes Ecoles de Commerce: Past, Present, and an Uncertain Future. Academy of Management Learning \& Education, 15(3), 549-568.

Hills, G.E., Lumpkin, G.T. and Singh, R.P. 1997. 'Opportunity Recognition: Perceptions and behaviours of entrepreneurs', in Reynolds, P.D., Carter, W.D., Davidsson, P. Gartner, W.B. and McDougall, P. (Eds.), Frontiers In Entrepreneurship Research. Wellesley, MA: Babson College. 
Hills, G. and Shrader, R. 1998. 'Successful entrepreneurs' insights into opportunity recognition'. In Reynolds, P.D., Bygrave, W.D., Carter, N.M., Manigart, S., Mason, C.M., Meyer, G.D., and Shaver, K.G. (Eds.), Frontiers of Entrepreneurship Research. Wellesley, MA: Babson College.

Instituto Nacional de Propiedad Industrial, 2011. Reporte INAPI 2011, Chile. Accessed January 16, 2019. https://www.inapi.cl/portal/publicaciones/608/articles-849_recurso_1.pdf

Instituto Nacional de Propiedad Industrial, 2016. Reporte INAPI 2016, Chile. Accessed January 16, 2019. https://www.inapi.cl/portal/publicaciones/608/articles-8495_recurso_1.pdf

Jaeger, A. J. and Thornton C. H. 2005. Moving toward the market and away from public service? Effects of resource dependency and academic capitalism. Journal of Higher Education Outreach and Engagement, 10(3), 53-67.

Karimi, S., Biemans, H. J. A., Lans, T., Chizari, M., and Mulder, M. 2016. The Impact of entrepreneurship education: A study of Iranian students' entrepreneurial intentions and opportunity identification. Journal of Small Business Management, 54(1), 187-209.

Karlsson, T., and Moberg, K. 2013. Improving perceived entrepreneurial abilities through education: exploratory testing of an entrepreneurial self-efficacy scale in a pre-post setting. The International Journal of Management Education, 11(1), 1-11.

Kezar, A. J. 2004. Obtaining integrity? Reviewing and examining the charter between higher education and society. The Review of Higher Education, 27(4), 429-459.

Kot, F. C., and Hendel, D. D. 2012. Emergence and growth of professional doctorates in the United States, United Kingdom, Canada and Australia: a comparative analysis. Studies in Higher Education, 37(3), 345-364. 
Kuratko, D. 2005. The Emergence of Entrepreneurship Education: Development, Trends, and Challenges. Entrepreneurship Theory and Practice, 29(5), 577-597.

Lahenius, K. 2012. Communities of practice supporting doctoral studies. The International Journal of Management Education, 10(1), 29-38.

Lackeus, M. 2014. An emotion based approach to assessing entrepreneurial education. The International Journal of Management Education, 12(3), 374-396.

Lean, J. 2012. Preparing for an uncertain future: the enterprising PhD student. Journal of Small Business and Enterprise Development, 19(3), 532-548.

Lester, S. 2004. Conceptualizing the practitioner doctorate, Studies in Higher Education, 29(6), 757-770.

Loi, M, Castriotta M., and Di Guardo, M.G. 2016. The theoretical foundations of entrepreneurship education: How co-citations are shaping the field. International Small Business Journal, 34(7), 948-971.

Loxley, A., and Seery, A. 2012. The role of the professional doctorate in Ireland from the student perspective, Studies in Higher Education, 37(1), 3-17.

Lumsdaine, E., and Binks, M. 2005. Entrepreneurship from Creativity to Innovation: Effective Thinking Skills for a Changing World. Trafford Publishing, United Kingdom.

Lüthje, C., and Franke, N. 2003. The Making of an entrepreneur: testing a model of entrepreneurial intent among engineering students at MIT. R\&D Management, 33(2), 135-147.

Malfroy, J. 2011. The impact of university-industry research on doctoral programs and practices, Studies in Higher Education, 36(5), 571-584.

Maresch, D., Harms, R., Kailer, N., and Wimmer-Wurmc, B. 2015. The impact of entrepreneurship education on the entrepreneurial intention of students in science and 
engineering versus business studies university programs. Technological Forecasting and Social Change, 104, 172-179.

Mars, M. M., Slaughter, S., and, Rhoades, G. 2008. The state-sponsored student entrepreneur. The Journal of Higher Education, 79(6), 638-670.

Mars, M. M., Bresonis, K., and Szelényi, K. 2014. Science and engineering doctoral student socialization, logics, and the national economic agenda: Alignment or disconnect? Minerva, $52,351-379$.

Martin, B., McNally, J., and Kay, M. 2013. Examining the formation of human capital in entrepreneurship: A meta-analysis of entrepreneurship education outcomes. Journal of Business Venturing, 28(2), 211-224.

Mathisen, J., and Arnulf, J. 2013. Competing mindsets in entrepreneurship: The cost of doubt. The International Journal of Management Education, 11, 132-141.

McGrath, R.G. and MacMillan, I.C. 2000. The Entrepreneurial Mindset: Strategies for Continuously Creating Opportunity in an Age of Uncertainty. Boston, MA: Harvard Business School Press.

McMillan, G. S., Narin, F., and Deeds, D. L. 2000. An analysis of the critical role of public science in innovation: The case of biotechnology. Research Policy, 29(1), 1-8.

Mendoza, P. 2007. Academic capitalism and doctoral student socialization: A case study. The Journal of Higher Education, 78(1), 71-96.

Ministerio de Economía, Fomento y Turismo. 2014. Sistema Nacional de Innovación 2010-2013: Principales avances y hechos relevantes desde la política pública. Chile. Accessed January 2019. Available at http://www.innovacion.cl/wpcontent/uploads/2014/03/SistemaNacional Innovacion.pdf 
Muñoz, C. A., Mosey, S., and Binks, M. 2011. Developing opportunity identification capabilities in the classroom: Visual evidence for changing mental frames. Academy of Management Learning and Education, 10(2), 277-295.

Mustar, P. 2009. Technology Management Education: Innovation and Entrepreneurship at MINES ParisTech, a Leading French Engineering School. Academy of Management Learning \& Education, 8(3), 418-425.

Nabi, G., Liñán, F., Fayolle, A., Krueger, N., and Walmsley, A. 2017. The impact of entrepreneurship education in higher education: A systematic review and research agenda. Academy of Management Learning \& Education, 16(2), 277-299.

OECD. 2008. Estudios de la OECD sobre políticas de innovación: Chile 2007. Ministry of the Economy, Development and Reconstruction. Chile. Accessed January 16, 2019. https://www.oecd-ilibrary.org/science-and-technology/estudios-de-la-oecd-sobre-politicasde-innovacion-chile-2007_9789264063532-es

Oosterbeek, H., Praag, M., and Ijsselstein, A. 2010. The impact of entrepreneurship education on entrepreneurship skills and motivation. European Economic Review, 54(3), 442-454.

Ortiz-Medina, L., Fernández-Ahumada, E,. Lara-Vélez, P., Taguas, E., Gallardo-Cobos, R., del Campillo M.C., and Guerrero-Ginel J.E. 2015. Designing an accompanying ecosystem to foster entrepreneurship among agronomic and forestry engineering students. Opinion and commitment of university lecturers. European Journal of Engineering Education, 41(4), 118.

Pruett, M., Shinnar, R., Toney, B., Llopis, F., and Fox, J. 2009. Explaining entrepreneurial intentions of university students: A cross-cultural study. International Journal of Entrepreneurial Behaviour \&amp; Research, 15(6), 571-594. 
Rauch, A.J., and Hulsink,W. 2015. Putting entrepreneurship education where the intention to act lies. An investigation into the impact of entrepreneurship education on entrepreneurial behaviour. Academy of Management Learning \& Education, 14(2), 187-204.

Roberts, G. 2002. SET for success: The supply of people with science, technology, engineering and mathematics skills, HM Treasury, London.

Roman, T., and Maxim, A. 2015. National culture and higher education as pre-determining factors of student entrepreneurship, Studies in Higher Education.

Salter, A. J., and Martin, B. R. 2001. The economic benefits of publicly funded basic research: a critical review. Research Policy, 30(3), 509-532.

Servage, L. 2009. Alternative and professional doctoral programs: what is driving the demand. Studies in Higher Education, 34(7), 765-779.

Shane, S. 2000. 'Prior knowledge and the discovery of entrepreneurial opportunities'. Organization Science, 11(4), 448-469.

Shane, S. 2004. Academic entrepreneurship: University spinoffs and wealth creation. Northhampton, MA: Edward Elgar Publishing Inc

Shepherd, D. and DeTienne, D. 2005 'Prior knowledge, potential financial reward, and opportunity identification'. Entrepreneurship Theory \& Practice, 29(1), 91-112.

Shinnar, R., Hsu, D., and Powel, B. 2014. Self-efficacy, entrepreneurial intentions, and gender: Assessing the impact of entrepreneurship education longitudinally. The International Journal of Management Education, 12(3), 561-570.

Singh, R.P., Hills, G.E., Hybels, R.C. and Lumpkin, G.T. 1999. 'Opportunity recognition through social network characteristics of entrepreneurs', in Reynolds, P.D., Bygrave, W.D., Manigart, S., Mason, C.M., Meyer, G.D., Sapienza, H.J. and Shaver 
Slaughter, S., and Leslie, L. 1997. Academic capitalism: Politics, policies, and the entrepreneurial university. Baltimore: Johns Hopkins University Press.

Slaughter, S., and Rhoades, G. 2004. Academic capitalism and the new economy: Markets, state, and higher education. Baltimore, MD: Johns Hopkins University Press.

Souitaris. V., Zerbinati, S., and Al-Laham, A. 2007. Do entrepreneurship programmes raise entrepreneurial intention of science and engineering students? The effect of learning inspiration and resources. Journal of Business Venturing, 22(4), 566-591.

Stephan, P., Sumell, A., Adams, J., and Black, G. 2005. Firm Placements of New PhDs: Implications for Knowledge Transfer, in: Fornahl, D., Zellner, C., Audretsch, D., (Eds.), The Role of Labour Mobility and Informal Networks for Knowledge Transfer. Springer, New York, pp. 125-146.

Strengers, Y A. 2014. Interdisciplinarity and industry collaboration in doctoral candidature: tensions within and between discourses, Studies in Higher Education, 39(4), 546-559.

Szelényi, K. 2013. The meaning of money in the socialization of science and engineering doctoral students: Nurturing the next generation of academic capitalists? The Journal of Higher Education, 84(2), 266-294.

Täks, M., Tynjälä, P., and Kukemelk, H. 2015. Engineering students' conceptions of entrepreneurial learning as part of their education. European Journal of Engineering Education, 41(1), 1-17.

Thune, T. 2009. Doctoral students on the university-industry interface: a review of the literature. Higher Education, 58, 637-651.

Ucbasaran, D., Westhead, P. and Wright, M. 2006. Habitual Entrepreneurs. Cheltenham, YK: Edward Elgar Publishing Limited. 
Ucbasaran, D., Westhead, P., Wright, M. and Binks, M. 2003. 'Does entrepreneurial experience influence opportunity identification?'. The Journal of Private Equity, 7, 7-14.

Van de Ven, A. H., and Poole, M. S. 2002. Field research methods, in Baum, J.A.C. (Ed.), Companion to Organizations. Blackwell, Oxford, pp. 867-888.

Vitae. 2011, "Research Development Framework". Accessed January 25, 2019. Available at https://www.vitae.ac.uk/vitae-publications/rdf-related/researcher-development-frameworkrdf-vitae.pdf/view.

Vitae. 2012, "Enterprise Lens on the Vitae Research Development Framework". Accessed January 25, 2019. Available at https://www.vitae.ac.uk/vitae-publications/rdf-related/enterpriselens-on-the-vitae-researcher-development-framework-rdf-apr-2012.pdf/view.

Von Graevenitz, G., Harhoff, D., and Weber, R. 2010. The effects of entrepreneurship education. Journal of Economic Behavior \& Organization, 76, 90-112.

Walsh, E., Hargreaves, C., Hillemann-Delaney, U., and Li, J. 2014. Doctoral researchers' views on entrepreneurship: ranging from 'a responsibility to improve the future' to 'a dirty word', Studies in Higher Education.

Wang, J.H., Chang, C.C., Yao. S.N., and Liang, C. 2016. The contribution of self-efficacy to the relationship between personality traits and entrepreneurial intention. Higher Education, 72(1), 209-224.

Warry, P. 2006, "Increasing the economic impact of research councils", 06/1678, Research Councils UK. Accessed January 9, 2019. Available at: https://www.cass.city.ac.uk/_data/assets/pdf_file/0006/73671/Warry20report.pdf

Yin, R. K. 2003. Case Study Research, Design and Methods, third ed. SAGE, London. 
Table 1: Participants of the study

\begin{tabular}{|l|l|l|l|l|}
\hline Participant & PHD Program & $\begin{array}{l}\text { Gender }- \\
\text { Age }\end{array}$ & $\begin{array}{l}\text { Entrepreneurial } \\
\text { Intention }\end{array}$ & $\begin{array}{l}\text { Prior } \\
\text { Entrepreneurial } \\
\text { Exposure }\end{array}$ \\
\hline Andrea & Food Processing & Female - 34 & Yes & Medium \\
\hline David & Neuroscience & Male - 31 & Yes & High \\
\hline Dubraska & Process & Female - 33 & No & High \\
\hline Gloria & Automation & Female - 36 & Yes & Low \\
\hline Jose & Automation & Male - 30 & No & Low \\
\hline Mauricio & Materials & Male -29 & Yes & High \\
\hline Manuel & $\begin{array}{l}\text { Computer } \\
\text { Sciences }\end{array}$ & Male -28 & Yes & Low \\
\hline Natalia & Food Processing & Female - 24 & Yes & Medium \\
\hline Renato & Materials & Male -32 & Yes & Low \\
\hline Roberto & Materials & Male -31 & No & High \\
\hline Rosa & Food Processing & Female - 29 & Yes & High \\
\hline Wladimir & Food Processing & Male - 28 & Yes & Low \\
\hline Yerko & Process & Male - 40 & Yes & High \\
\hline
\end{tabular}


Table 2: Effects of the course on doctoral projects

\begin{tabular}{|c|c|c|c|}
\hline Participant & Applied Vision & New problem solving approaches & Not repport effects \\
\hline Andrea & & & $\begin{array}{l}\text { "The truth is that it served me for my post- } \\
\text { doctoral project" ( } 2^{\text {nd }} \text { Interview) "Not on } \\
\text { the topic of the thesis, but it has served me } \\
\text { later." ( } 3^{\text {rd }} \text { Interview) }\end{array}$ \\
\hline David & $\begin{array}{l}\text { "that it was even more innovative and } \\
\text { it would be a better solution and I dare } \\
\text { to think that I can get it off the shelf as } \\
\text { a thesis and transform it into a } \\
\text { product" (Impact of the course) ( } 3^{\text {rd }} \\
\text { Interview) }\end{array}$ & $\begin{array}{l}\text { "The course was fundamental because it } \\
\text { allowed me to look at the problems from } \\
\text { other perspectives and other prisms, it } \\
\text { helped me to look for more creative } \\
\text { solutions or (at least) different to the } \\
\text { ones I was looking at, even looking } \\
\text { outside the scientific context to be able } \\
\text { to explain the phenomena that I am } \\
\text { seeing and to be able to answering the } \\
\text { question that I had not been able to } \\
\text { answer until now, it helped me a lot." } \\
\text { (2 Interview) }\end{array}$ & \\
\hline Dubraska & & $\begin{array}{l}\text { "I am just in the data analysis stage and } \\
\text { the course allowed me to question } \\
\text { myself a little more about different } \\
\text { points from the same date. It has allowed } \\
\text { me to question the data, to see a little } \\
\text { further, to see if the data is well taken, if } \\
\text { the problem I am raising is the real one } \\
\text { or we can go a little further." ( } 2^{\text {nd }} \\
\text { Interview) }\end{array}$ & \\
\hline Gloria & $\begin{array}{l}\text { "To feel confident to continue with the } \\
\text { project and think of it as a business" } \\
\text { (Impact of the course) ( } 2^{\text {nd }} \text { Interview) }\end{array}$ & $\begin{array}{l}\text { "Mainly having a broader view of the } \\
\text { things one can do with the same idea.I } \\
\text { had the fixed idea of building a crane, } \\
\text { but I realized that I could actually pull } \\
\text { out other information and get another } \\
\text { benefit while I wasn't able to build it" } \\
\text { ( } 3^{\text {rd }} \text { Interview) }\end{array}$ & \\
\hline Mauricio & $\begin{array}{l}\text { "It changes the vision of the project } \\
\text { and it is not only seen as a research but } \\
\text { now I see it as a development project, } \\
\text { which can be incorporated into the } \\
\text { business system or in this case to the } \\
\text { miner's." "The contribution was broad } \\
\text { because I saw my project as a } \\
\text { scientific issue, not as a development } \\
\text { issue ... it started as an idea of only } \\
\text { doing a research, and now I am in } \\
\text { search of its potential development in } \\
\text { the industry" ( } 2^{\text {nd }} \text { Interview) }\end{array}$ & $\begin{array}{l}\text { "Yes, it helped me a little to develop the } \\
\text { topics we had set ourselves, we set some } \\
\text { goals and it helped us a lot to see the } \\
\text { development and how to raise the } \\
\text { development of those questions." "The } \\
\text { vision the course gave was helpful on } \\
\text { how focus the study of the project ... it } \\
\text { helped me to raise the questions we had } \\
\text { and made it easier to focus on the } \\
\text { methodology of work"( } 3^{\text {rd }} \text { Interview) }\end{array}$ & \\
\hline
\end{tabular}




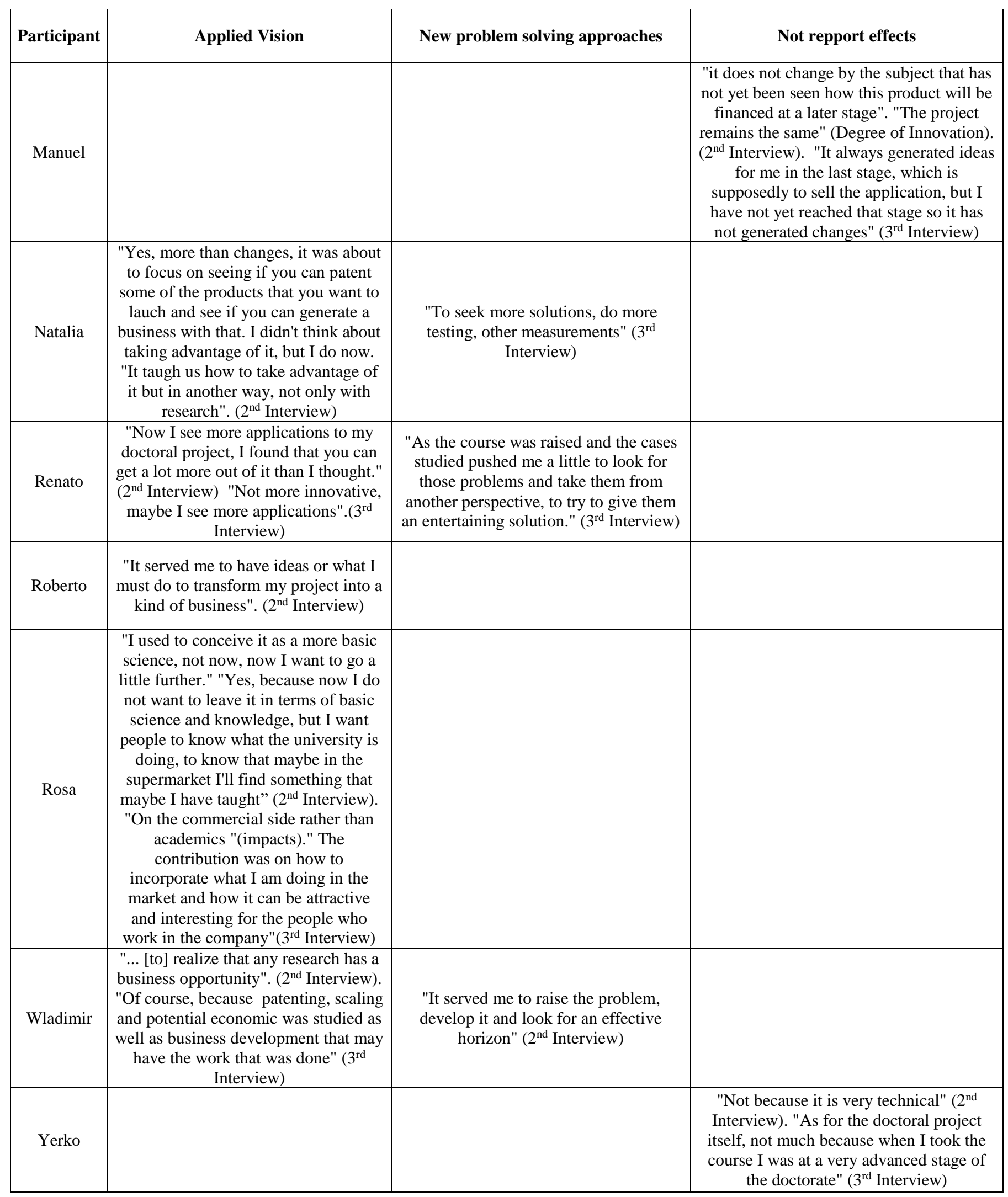


Table 3: Effects of the course on communication skills and understanding of entrepreneurship

\begin{tabular}{|c|c|c|}
\hline Participant & Improve communication and "sale ideas" & $\begin{array}{c}\begin{array}{c}\text { Practical understanding of } \\
\text { entrepreneurship }\end{array} \\
\end{array}$ \\
\hline Andrea & - & - \\
\hline David & $\begin{array}{l}\text { "... to look for new edges on how to find more answers } \\
\text { and more convincing for my postulates..." ( } 3^{\text {rd }} \\
\text { Interview) }\end{array}$ & $\begin{array}{l}\text { "Really good (the course) because it gave } \\
\text { me fundamentals, I had like the restlessness } \\
\text { and had made a couple of undertakings, and } \\
\text { here I had theoretical and practical } \\
\text { foundations of what to do, how to do, why } \\
\text { to do it and what alternatives I have"( } 2^{\text {nd }} \\
\text { Interview) }\end{array}$ \\
\hline Dubraska & $\begin{array}{l}\text { "[The course] was quite enriching even in improving on } \\
\text { presentations and how to sell your idea" ( } 2^{\text {nd }} \text { Interview) } \\
\text { "I have tried, through the course, to make more } \\
\text { effective presentations because they are one of the } \\
\text { things like that the entrepreneur at the end has an idea } \\
\text { that sometimes does not know how to sell. So doing it in } \\
5 \text { minutes is what I have tried to practice." ( } 3^{\text {rd }} \\
\text { Interview) }\end{array}$ & - \\
\hline Gloria & $\begin{array}{l}\text { "Now it has been easier for me to look for funding } \\
\text { sources because now I know what to do, what to say, } \\
\text { how to deal with it, what to write, what to think about } \\
\left.\text { the client" ( } 2^{\text {nd }} \text { Interview }\right)\end{array}$ & $\begin{array}{l}\text { "I already have a structure that allows me to } \\
\text { know the steps that I must follow [to carry } \\
\text { out an entrepreneurship project]. Unlike } \\
\text { before, I think about it now" ( } 3^{\text {rd }} \text { Interview) }\end{array}$ \\
\hline Jose & $\begin{array}{l}\text { "To show business ideas to others, things that may not } \\
\text { have been so clear before." ( } 2^{\text {nd }} \text { Interview) }\end{array}$ & - \\
\hline Mauricio & $\begin{array}{l}\text { "It helps to have at least an idea of what is to be faced } \\
\text { first to have a company, or an idea that can be presented } \\
\text { to a company" ( } 3^{\text {rd }} \text { Interview) }\end{array}$ & - \\
\hline Manuel & $\begin{array}{l}\text { "The main contribution [of the course] was on how to } \\
\text { convince someone who can help me to finance a } \\
\text { business idea" ( } 2^{\text {nd }} \text { Interview) }\end{array}$ & - \\
\hline Natalia & $\begin{array}{l}\text { "In general, it served me both to write more persuasively } \\
\left.\text { and to look for other options"( } 2^{\text {nd }} \text { Interview }\right)\end{array}$ & - \\
\hline Renato & $\begin{array}{c}\text { "I would say quite a lot about understanding how and } \\
\text { what were the most important soft skills to manage an } \\
\text { undertaking." ( } 2^{\text {nd }} \text { Interview) }\end{array}$ & - \\
\hline Roberto & - & $\begin{array}{c}\text { "[The course }] \text { helped me to understand } \\
\text { what I must do to transform my project into } \\
\text { a business" ( } 2^{\text {nd }} \text { Interview) }\end{array}$ \\
\hline Rosa & $\begin{array}{l}\text { "You cannot just go and talk, you have to go with a } \\
\text { backup so that the one who is going to invest has the } \\
\text { clear information" ( } 3^{\text {rd }} \text { Interview) }\end{array}$ & $\begin{array}{l}\text { "They taught me what steps I should take if I } \\
\left.\text { wanted to undertake"( } 2^{\text {nd }} \text { Interview }\right)\end{array}$ \\
\hline Wladimir & - & - \\
\hline Yerko & - & - \\
\hline
\end{tabular}




\section{Table 4: Effects of the course on entrepreneurial intentions}

\begin{tabular}{|c|c|c|c|c|}
\hline Participant & Degree of initial entrepreneurial intention & $\begin{array}{c}\text { Greater intention to commercialize their } \\
\text { research }\end{array}$ & $\begin{array}{c}\text { Changes in general entrepreneurial } \\
\text { intention }\end{array}$ & Remove mental barriers \\
\hline Andrea & $\begin{array}{c}\text { "Yes, I think so because I'm really looking } \\
\text { forward to it" (start a company). "Because I } \\
\text { want to start my company" (because she took } \\
\text { the course) ( } 1^{\text {st }} \text { Interview) }\end{array}$ & & & $\begin{array}{l}\text { "I realized that we can all be } \\
\text { entrepreneurs, it is a matter of } \\
\left.\text { proposing it" ( } 2^{\text {nd }} \text { Interview }\right)\end{array}$ \\
\hline David & $\begin{array}{l}\text { "Yes, it is already in progress. Perhaps from the } \\
\text { doctoral thesis emerges one, there are more } \\
\text { ideas" (Creating a company sometime in life) } \\
\text { ( } 1^{\text {st }} \text { Interview) }\end{array}$ & $\begin{array}{l}\text { "Yes, of course it's super necessary" (he } \\
\text { believes more than before that he could develop } \\
\text { a company to explain results of his research). } \\
\text { "Yes, of course" (he has greater intention to } \\
\text { create company through his research). ( } 2^{\text {nd }} \\
\text { Interview)."Yes, sure, that is, I have a company } \\
\text { that is not from my thesis but that it's going to } \\
\text { tend that way" (Greater intention to create a } \\
\text { company after his research) ( } 3^{\text {rd }} \text { Interview) }\end{array}$ & & $\begin{array}{l}\text { "But above all else to think that I } \\
\text { could undertake" ( } 3^{\text {rd }} \text { Interview) }\end{array}$ \\
\hline Dubraska & $\begin{array}{c}\text { "Well, it would be ideal, but so far I have not } \\
\text { consider it" (commercially exploiting research } \\
\text { results) ( } 1^{\text {st }} \text { Interview) }\end{array}$ & $\begin{array}{l}\text { "Developing a company from my research is } \\
\text { my next project, because it is something I want } \\
\left.\text { to do now". ( } 2^{\text {nd }} \text { Interview }\right)\end{array}$ & & \\
\hline Gloria & $\begin{array}{l}\text { "It is not my ultimate goal, but it is within the } \\
\text { ideas that can be given." "I'm not that certain } \\
\text { about creating the company or a product that } \\
\text { could be sold". "I think so" (Creating a } \\
\text { company sometime). ( } 1^{\text {st }} \text { Interview) }\end{array}$ & $\begin{array}{l}\text { "Yes, that's the final idea, that's where we're } \\
\text { going" (Believes more than before being able to } \\
\text { develop a company as a result of research). ( } 2^{\text {nd }} \\
\text { Interview) }\end{array}$ & & \\
\hline Jose & $\begin{array}{l}\text { "" No "(Aim to start a company through his } \\
\text { research)." "I think so"(He will ever start his } \\
\text { company) "I do not know, I think that one can } \\
\text { think in different ways, from the moment one } \\
\text { thought to study and not to stay without } \\
\text { studying, you are undertaking in some way, but } \\
\text { I do not consider myself to be always worried } \\
\text { about undertaking" (Entrepreneurial concept no } \\
\text { related) ( } 1 \text { st Interview) }\end{array}$ & & $\begin{array}{l}\text { "I'm not very sure, but I think so, more } \\
\text { than before." "Before, maybe it was zero, } \\
\text { now I'm like maybe, but I'm not } 100 \% \\
\text { sure" ( } 2^{\text {nd }} \text { Interview). "I think so ... I think } \\
\text { it is more feasible" (believes more than } \\
\text { before about the possibility of creating a } \\
\text { company through research) ( } 3^{\text {rd }} \text { Interview) }\end{array}$ & \\
\hline
\end{tabular}




\begin{tabular}{|c|c|c|c|c|}
\hline Participant & Degree of initial entrepreneurial intention & $\begin{array}{c}\text { Greater intention to commercialize their } \\
\text { research }\end{array}$ & $\begin{array}{c}\text { Changes in general entrepreneurial } \\
\text { intention }\end{array}$ & Remove Barriers \\
\hline Mauricio & $\begin{array}{l}\text { "It has to do with a development to later } \\
\text { become independent and to start a company or } \\
\text { something like that" (because he takes the } \\
\text { doctorate) ( } 1^{\text {st }} \text { Interview) }\end{array}$ & $\begin{array}{l}\text { "Yes" (greater intention to create a company } \\
\text { from research than before the course) } \\
\left.\text { ( } 2^{\text {nd }} \text { Interview }\right)\end{array}$ & & $\begin{array}{l}\text { "It served me mainly to break the } \\
\text { paradigm I had of entrepreneurs. } \\
\text { I conceived them as enlightened } \\
\text { people ... I realized that it is more } \\
\text { about the desire of doing } \\
\text { something and want to develop } \\
\text { it, than being a brilliant person" } \\
\text { ( } 3{ }^{\text {rd }} \text { Interview) }\end{array}$ \\
\hline Manuel & $\begin{array}{l}\text { "Yes, I once thought about it, but now I do not } \\
\text { know if so much" "Maybe, I do not rule out that } \\
\left.\text { possibility" ( } 1{ }^{\text {st }} \text { Interview }\right)\end{array}$ & & $\begin{array}{l}\text { "Now I have ideas for everything, not just } \\
\text { for my doctoral thesis" ( } 3^{\text {rd }} \text { Interview) }\end{array}$ & \\
\hline Natalia & $\begin{array}{l}\text { "I do not know if creating but maybe a } \\
\text { company that already exists may want to use } \\
\text { the final product" (result of the research). "Yes" } \\
\text { (believes that she will ever start a business) ( } 1^{\text {st }} \\
\text { Interview) }\end{array}$ & $\begin{array}{l}\text { "Yes" (She has more intentions to create a } \\
\text { company from her research than before the } \\
\text { course) }\left(2^{\text {nd }} \text { Interview }\right)\end{array}$ & $\begin{array}{l}\text { "Yes" (believes he will ever start his own } \\
\text { company) ( } 2^{\text {nd }} \text { Interview). "Yes, creating a } \\
\text { company, but I do not know if from my } \\
\text { research, maybe another area that can be } \\
\text { explored" ( } 3^{\text {rd }} \text { Interview) }\end{array}$ & $\begin{array}{l}\text { "The vision that it gave me has to } \\
\text { do with anyone being an } \\
\text { entrepreneur, you just have to } \\
\text { have the desire and look for } \\
\text { opportunities in the world" ( } 3^{\text {rd }} \\
\text { Interview) }\end{array}$ \\
\hline Renato & $\begin{array}{c}\text { "It would be nice but it is not my goal. (Start a } \\
\text { company from his research)) "Yes" (He thinks } \\
\text { he will start his own company) "I would not } \\
\text { want to spend my whole life in this and maybe } \\
\text { one day I will just go ahead and seek solutions } \\
\text { to problems that I believe are really valuable" } \\
\text { ( } 1^{\text {st }} \text { Interview) }\end{array}$ & & & \\
\hline Roberto & $\begin{array}{l}\text { (1) "No" (Aims to create a company with } \\
\text { research) "No. the academic world is what I } \\
\text { want, thinking about creating a company would } \\
\text { be a huge investment, I think I am not willing } \\
\text { to take the risk." (He thinks that sometime will } \\
\text { start his company). ( } 1^{\text {st }} \text { Interview) }\end{array}$ & & $\begin{array}{l}\text { "I really don't think so." (Start his own } \\
\text { business) }\left(2^{\text {nd }} \text { Interview }\right)\end{array}$ & \\
\hline
\end{tabular}




\begin{tabular}{|c|c|c|c|c|}
\hline Participant & Degree of initial entrepreneurial intention & $\begin{array}{c}\text { Greater intention to commercialize their } \\
\text { research }\end{array}$ & $\begin{array}{c}\text { Changes in general entrepreneurial } \\
\text { intention }\end{array}$ & Remove Barriers \\
\hline Rosa & $\begin{array}{c}\text { "Sooner or later" (Creating a company) (1 } 1^{\text {st }} \\
\text { Interview) }\end{array}$ & & $\begin{array}{l}\text { "Yes. Maybe not with the doctoral project, } \\
\text { but with lots of ideas we had where we } \\
\text { could maybe start with an SME, with a } \\
\text { small project where later we can do } \\
\text { something more." (2nd Interview) }\end{array}$ & \\
\hline Wladimir & $\begin{array}{l}\text { "Not from my current results, but from } \\
\text { opportunities that I have seen in the same } \\
\text { laboratory." (Aims to create a company with } \\
\text { research) "Yes, I have to do it". (Create a } \\
\text { company) ( } 1^{\text {st }} \text { Interview) }\end{array}$ & $\begin{array}{l}\text { "From my research, of course, that does not } \\
\text { mean that I continue with the same subject of } \\
\text { the doctoral thesis. I try to always look for the } \\
\text { application to the subjects that I am thinking to } \\
\text { investigate. I want to go further and hopefully } \\
\text { to have an impact on development that is what } \\
\text { we all seek " ( } 3^{\text {rd }} \text { Interview) }\end{array}$ & $\begin{array}{c}\text { "Not from my particular research, but I } \\
\text { have other ideas. I have ideas that I would } \\
\text { like to be able to exploit to the fullest and I } \\
\text { know now that they could have some } \\
\text { potential". ( } 2^{\text {nd }} \text { Interview) }\end{array}$ & $\begin{array}{l}\text { "I had the possibility to expand } \\
\text { my mind a little bit compared to } \\
\text { where I started from. I got rid off } \\
\text { a lot of prejudices, like always } \\
\text { thinking that everything is } \\
\text { complicated, everything here has } \\
\text { to be so square, suddenly there } \\
\text { are things so simple that you do } \\
\text { not see them, because when you } \\
\text { start to study a lot, you go } \\
\text { deeper, you get more complex, } \\
\text { you do not see things as clearly } \\
\text { as a child could. Person's mind } \\
\text { turns complex. (2 } 2^{\text {nd }} \text { Interview) }\end{array}$ \\
\hline Yerko & $\begin{array}{l}\text { "Sure" (Objective to create company through } \\
\text { research) }\left(1^{\text {st }} \text { Interview) }\right.\end{array}$ & & & \\
\hline
\end{tabular}

